\title{
疎水化ヒドロキシプロピルメチルセルロースを用いたリポソームの架橋とレオロジー特性
}

\author{
橋崎 $\quad$ 要, ${ }^{*}, a$ 梅田里紗, ${ }^{a}$ 三浦基文, ${ }^{b}$ 田口博之, ${ }^{a}$ 藤井まき子 $a$
}

\section{Preparation and Rheological Properties of Cross-linked Liposomes Using Hydroxypropylmethylcellulose Bearing a Hydrophobic Anchor}

\author{
Kaname Hashizaki, ${ }^{*},{ }^{a}$ Risa Umeda, ${ }^{a}$ Motofumi Miura, ${ }^{b}$ Hiroyuki Taguchi, ${ }^{a}$ and Makiko Fujii ${ }^{a}$ \\ ${ }^{a}$ Laboratory of Physical Chemistry, School of Pharmacy, Nihon University; 7-7-1 Narashinodai, Funabashi, \\ Chiba 274-8555, Japan: and ${ }^{b}$ Laboratory of Molecular Chemistry, School of Pharmacy, \\ Nihon University; 7-7-1 Narashinodai, Funabashi, Chiba 274-8555, Japan.
}

(Received October 27, 2019; Accepted December 5, 2019)

\begin{abstract}
Hydrophobically-modified hydroxypropylmethylcellulose (HM-HPMC) is a thickener with a long hydrophobic alkyl side chain. In this study, we investigated the gelation ability and rheological properties of a liposome/HM-HPMC mixed solution. The liposome suspension and the HM-HPMC aqueous solution each had low viscosities, but the viscosity increased rapidly when they were mixed. This is thought to be due to the formation of a 3D network structure caused by the hydrophobic group of HM-HPMC penetrating into the liposomal bilayer membrane, crosslinking the liposomes together. This hypothesis was supported by the fact that gelation did not occur when hydroxypropylmethylcellulose without a hydrophobic group was used. The viscosity of the liposome/HM-HPMC mixed solution decreased rapidly when a shear was applied, but immediately returned to the original gel state when the shear was removed, indicating a reversible reaction. When a strong shear is applied, the hydrophobic group of HM-HPMC detaches from the liposome. When the shear is removed, the liposome is again cross-linked by HM-HPMC. From these results, it was revealed that liposome cross-linked gels can be prepared when HM-HPMC is used.
\end{abstract}

Key words - liposome; hydrophobically-modified hydroxypropylmethylcellulose; hydrogel; crosslink; small angle X-ray scattering; rheology

\section{緒}

言

リポソームは, 生体膜の主要構成成分であるリン 脂質からなる二分子膜の閉鎖小胞体である. ${ }^{1)}$ リポ ソームは生体適合性が高く, 二分子膜及び内水相に 様々な薬物を封入できることから，薬物送達システ ムにおける薬物運搬体として利用されている.

近年，リポソームと水溶性高分子ゲルの両方の性 質を併せ持つハイブリッド材料の開発が試みられて おり，水溶性高分子が形成する 3 次元網目構造中に リポソームが埋め込まれたゲル2)や，部分的に疎水 化した水溶性高分子でリポソームを架橋したゲ ル3-11)が報告されている，後者は，アルキル基やコ レステロール基といつた疎水基を化学修飾した疎水 化水溶性高分子を利用するもので，リポソームに作

${ }^{a}$ 日本大学薬学部薬品物理化学研究室, ${ }^{b}$ 日本大学薬学 部薬品分子化学研究室

*e-mail: hashizaki.kaname@nihon-u.ac.jp
用させるとそれらが複合体を形成してゲル化するこ とが知られている。これは水溶性高分子に導入され た疎水基のアンカー効果によって，リポソームが架 橋されるために生じる。このリポソーム架橋ゲルの 特徵はその粘度のずり依存性にあり, 強いずりを加 えると水溶性高分子の疎水基がリポソームから抜け 落ちて粘度が急激に低下する。このような特徵か ら，リポソーム架橋ゲルは注射によって体内への注 入が可能で，体内に入ると再びゲルを形成すること から，インジェクタブルゲル製剤として医療分野で の利用が期待されている. ${ }^{10)}$ 一方, リポソームに作 用させる疎水化水溶性高分子としては，ポリアクリ ル酸ナトリウムやポリオキシエチレン等の合成高分 子の誘導体 $3,4,6)$ のほか, セルロースやキトサン, ア ルギン酸ナトリウム等の天然高分子の誘導体 $5,7-11)$ が報告されている。しかしながら，それらのほとん どが主鎖又は側鎖に電荷を持つ高分子電解質である ため，無機塩や pH の影響を受けてゲルが崩壊して 

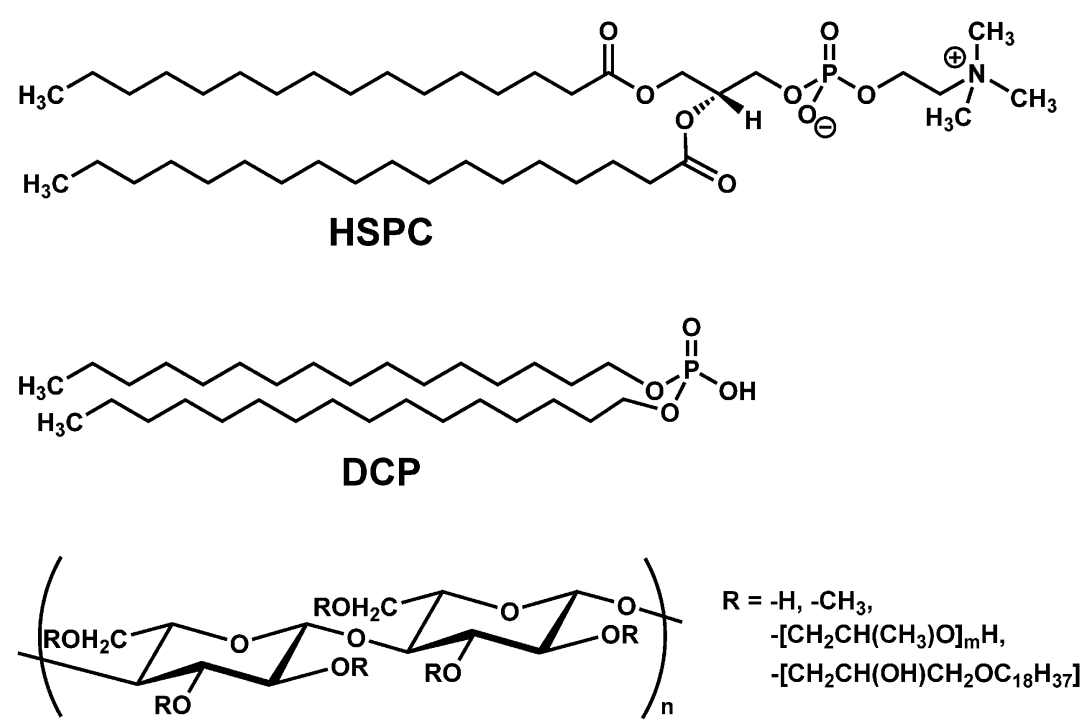

HM-HPMC

Fig. 1. Chemical Structure of the Molecules Used in This Study

しまうケースがある.

そこで本研究では，リポソームの架橋に $\mathrm{pH}$ 安定 性と耐塩性を有する疎水化ヒドロキシプロピルメチ ルセルロース (hydrophobically-modified hydroxypropylmethylcellulose; HM-HPMC) を用いた. ヒ ドロキシプロピルメチルセルロース（hydroxypropylmethylcellulose; HPMC) は，セルロースの メチル及びヒドロキシプロピルの混合エーテルであ り，製剤添加物（結合剂，増粘剤，コーティング 剂，懸濁化剂，崩壊剂，分散剤等）として経口製剤 及び局所製剂に広く使用されている. ${ }^{12)}$ 一方，HMHPMC は，上述した HPMC のステアリルオキシ ヒドロキシプロピルエーテルであり， HPMC に比 べて高い界面活性や増粘効果を示すことが知られて

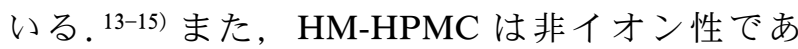
り，酸・塩基の影響を受け難く，電解質との配合安 定性に優れている。 そのため，HM-HPMC を用い てリポソームを架橋することができれば，様々な薬 物を配合できるうえに，生体内での安定性の向上も 期待できる，そこで本論文では，HM-HPMC を用 いたリポソームの架橋とそのレオロジー特性を詳細 に検討した.

\section{方法}

1. 試薬 水素添加大豆リン脂質 (hydrogenated soy phosphatidylcholine; HSPC) は, 日光ケミ
カルズ (株) (東京) の NIKKOL レシノール S-10EX（ホスファチジルコリン含量 $95 \%$ 以上）を 使用した，荷電物質であるジセチルリン酸（dicetyl phosphate; DCP) は, Sigma-Aldrich (St. Louis) のものを使用した。クロロホルムは関東化学 (株) （東京）のものを使用した。 HM-HPMC は，大同 化成工業(株) (大阪) のサンジェロース 60L（ステ アリルオキシヒドロキシプロポキシル基の置換率が 0.3-0.6\%）を使用した。 HPMC は，信越化学工業 (株)（東京）のメトローズ 60SH10000を使用した. 水は注射用水を使用した。 Figure 1 には，HSPC， DCP 及び HM-HPMC の構造式を示す.

2. HM-HPMC 水溶液の調製注射用水を ホットプレートスターラーで約 $80^{\circ} \mathrm{C}$ に加温し, HM-HPMC を加えて約 1 分間擋汼した。 その後, 水浴中で 30 分間擋挥して, $2.0 \%$ HM-HPMC 水溶 液を調製した。

3.リポソーム懸濁液の調製、リポソームは常 法に従つて作製した. ${ }^{1)}$ HSPC $0.093 \mathrm{~g}$ と DCP $0.007 \mathrm{~g}$ を容量 $14 \mathrm{~mL}$ のガラス製の試験管に量り取り，ク ロロホルムを加えて溶解後, 窒素ガスを吹き付けて 溶媒を除去することにより試験管壁面に脂質薄膜を 形成させた．さらに，クロロホルムを完全に除去す るために減圧デシケータ中に一昼夜放置し，これに リン脂質濃度（HSPC と DCP の合計）が $2.0 \%$ と なるように注射用水 $4.9 \mathrm{~g}$ を加えて $65^{\circ} \mathrm{C}$ で水和・ 
膨潤し，ボルテックスミキサーで振とうして多重膜 リポソームを調製した。これを $65^{\circ} \mathrm{C}$ の温浴中で加 温しながら 10 分間超音波処理を行い, 小さな一枚 膜リポソームを作製した。なお，本研究で作製した リポソームは DCP による負電荷を有しているた め, 凝集を起こし難い。リポソームの粒子径及び ゼー夕電位は， $2.0 \%$ リポソーム懸濁液を注射用水 で適当に希釈し，ゼー夕電位・動的光散乱測定装置 (Nicomp380 ZLS, Particle Sizing Systems Inc., Santa Barbara）を用いて, 動的光散乱法及び電気泳動光 散乱法により測定した.

4. リポソームと HM-HPMC 混合溶液の調製 あらかじめ調製しておいた $2.0 \%$ リ゚ソーム懸濁 液， $2.0 \% \mathrm{HM}-\mathrm{HPMC}$ 水溶液及び注射用水を任意 の割合で混合して調製した。例えば，混合溶液中の リン脂質濃度及び HM-HPMC 濃度がそれぞれ, $1.5 \%$ 及び $0.3 \%$ の混合溶液は， $2.0 \%$ リポソーム懸 濁液 $1.5 \mathrm{~g}$ と $2.0 \% \mathrm{HM}-\mathrm{HPMC}$ 水溶液 $0.3 \mathrm{~g}$ に注射 用水 $0.2 \mathrm{~g}$ を加えて混合調製した。

5. レオロジー測定 レオロジー測定は，粘 度・粘弾性測定装置 (HAAKE RS600 及び HAAKE MARS III, Thermo Fischer Scientific Inc., Waltham) を使用して $25^{\circ} \mathrm{C}$ で行った。 また，溶媒の蒸発を防 止するためにソルベントトラップを用いた。 セン サーの形状は試料の粘度に合わせて選択し，コーン 型（直径 $35 \mathrm{~mm}$ 又は $60 \mathrm{~mm}$ ，角度 $1^{\circ}$ ）, ダブルコー ン型（直径 $60 \mathrm{~mm}$, 角度 $1^{\circ}$ ）及びパラレル型（直 径 $60 \mathrm{~mm}$ ，ギャップ $0.5 \mathrm{~mm}$ ）を使用した。定常流 粘度測定では，段階的に剪断応力を上げていき，各 ステップで剪断速度の定常值を測定して粘度を求め た。構造回復測定では，剪断速度を $0.5 \mathrm{~s}^{-1} \rightarrow 50 \mathrm{~s}^{-1}$ $\rightarrow 0.5 \mathrm{~s}^{-1}$ の順に変化させたときの粘度の回復率を 調べた。動的粘弾性測定では, 線形粘弾性領域内の ひずみを用いて，貯蔵弾性率 $\left(G^{\prime}\right)$ 及び損失弾性 率 $\left(G^{\prime \prime}\right)$ の周波数依存性を調べた。

6. 小角 $\mathbf{X}$ 線散乱測定 小角 $\mathrm{X}$ 線散乱（small angle X-ray scattering; SAXS) 測定は, SPring-8 (佐用)において非結晶小角広角散乱回析実験用ビー ムライン（BL40B2）を用いて行った。試料は直径 $2 \mathrm{~mm}$ の石英ガラスキャピラリーに封入した．X 線 の波長は $0.1 \mathrm{~nm}$, カメラ長は $2000 \mathrm{~mm}$, 検出器に は大面積型ピクセル検出器（PILATUS-3S 2M, DECTRIS Ltd., Baden) を用いた。なお，測定は
Table 1. Gelation Ability of Liposome/HM-HPMC Mixed Solutions

\begin{tabular}{ll|cccc}
\hline \hline & & \multicolumn{4}{|c}{ HM-HPMC concn. (\%) } \\
& & 0 & 0.1 & 0.25 & 0.3 \\
\hline & 0 & $\times$ & $\times$ & $\times$ & $\times$ \\
Phospholipid & 0.5 & $\times$ & $\times$ & $\times$ & $\bigcirc$ \\
concn. (\%) & 1.0 & $\times$ & $\times$ & $\bigcirc$ & $\bigcirc$ \\
& 1.25 & $\times$ & $\times$ & $\bigcirc$ & $\bigcirc$ \\
& 1.5 & $\times$ & $\times$ & $\bigcirc$ & $\bigcirc$ \\
\hline
\end{tabular}

: Gel, $\times$ : Sol.

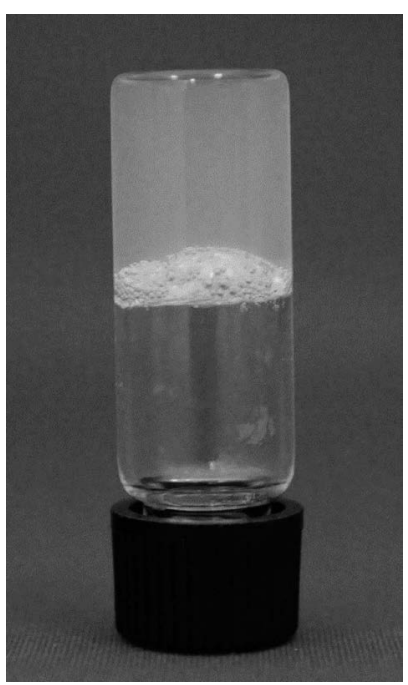

Fig. 2. Appearance of a $1.5 \%$ Liposome/0.3\% HM-HPMC Mixed Solution

$25^{\circ} \mathrm{C}$ で行つた.

\section{結果及び考察}

1.リポソーム/ HM-HPMC 混合溶液の性状 混合前のリポソーム懸濁液について粒子径及び ゼー夕電位を測定したところ，平均粒子径は約 $140 \mathrm{~nm}$ ，ゼー夕電位は約 $-40 \mathrm{mV}$ のリポソームが 形成していることがわかった。このリポソーム懸濁 液と HM-HPMC 水溶液を混合した際の流動性を目 視によって確認した. Table 1 は, サンプルを容器 ごと上下反転させた際に，垂れなかったものを $○ ，$

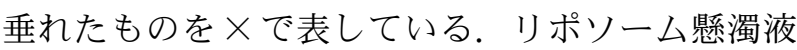
及び HM-HPMC 水溶液は，混合前はいずれの濃度 においても×の判定であったが，混合後はリン脂 質濃度と HM-HPMC 濃度に依存して○で示すゲル 化領域が広がることがわかった. Figure 2 には一例 として， $1.5 \%$ リホソーム $/ 0.3 \%$ HM-HPMC 混合 溶液の外観を示す．混合溶液はわずかに青白く半透 
明で，適度な粘弾性を有していた。そこで，ゲル中 におけるリポソームの溶存状態を調べるために SAXS 測定を行った.

Figure 3 には，1.0\%リポソーム懸濁液及び 1.0\% リポソーム $/ 0.25 \%$ HM-HPMC 混合溶液の散乱曲 線（散乱べクトル $q$ と散乱強度 $I(q)$ の関係）を示 す。ここで $q=4 \pi \sin \theta / \lambda$ で， $\theta$ は散乱角， $\lambda$ は X 線の波長である。一般に, 多重膜リポソームやラメ ラ液晶の散乱曲線では，構造単位である二分子膜構 造の周期性が複数の鋭い等距離ピークとして観測さ れる. ${ }^{16)}$ しかしながら，本研究で調製したリポソー ムの散乱曲線においては，そのような鋭い複数ピー クは観測されなかったことから，一枚膜リポソーム が形成していると考えられる，さらに，二分子膜等 の平板構造の散乱曲線では，両対数プロットの低 $q$ 領域における直線の傾きがー 2 を示すことが知られ ている. ${ }^{17,18)}$ 結果より，いずれの散乱曲線において も低 $q$ 領域に傾き -2 の直線部分を認めたことか ら，二分子膜構造の存在を確認した。また，HMHPMC を添加しても散乱曲線全体の形状はほとん ど変化しなかったことから，二分子膜の厚さや内部 電子密度分布といった局所構造もほとんど変化して

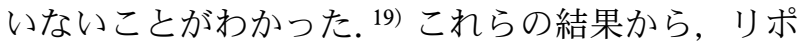
ソームはゲル中にその構造を維持したまま存在して いることが示唆された。

2.リポソーム/HM-HPMC 混合溶液のレオロ ジー特性、リポソーム/HM-HPMC 混合溶液の 流動性を明らかにするために粘度測定を行った。

Figure 4 には，HM-HPMC 濃度を $0.3 \%$ に固定し， リン脂質濃度を変化させた混合溶液の剪断速度と粘 度の関係を示す。結果より，剪断速度が遅いと ニュートン流動を示すが，剪断速度が速くなると非 ニュートン流動を示すことがわかった。また，リン 脂質濃度が高くなるほどニュートン流動域の粘度が 大きくなり，リン脂質濃度が $1 \%$ を超えると粘度の 増加は鈍くなった。なお，得られたゲルは，18-25 G の注射針を通して容易に押し出すことができた。

Figure 5 には，リン脂質濃度及び HM-HPMC 濃 度を変化させた際の混合溶液のゼロ剪断粘度を示

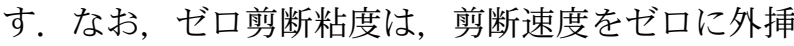
したときの粘度のことで，Fig. 4 のニュートン流動 域における粘度值に等しい。結果より，リポソーム 懸濁液単独のゼロ剪断粘度は，リン脂質濃度が 0.5 ,
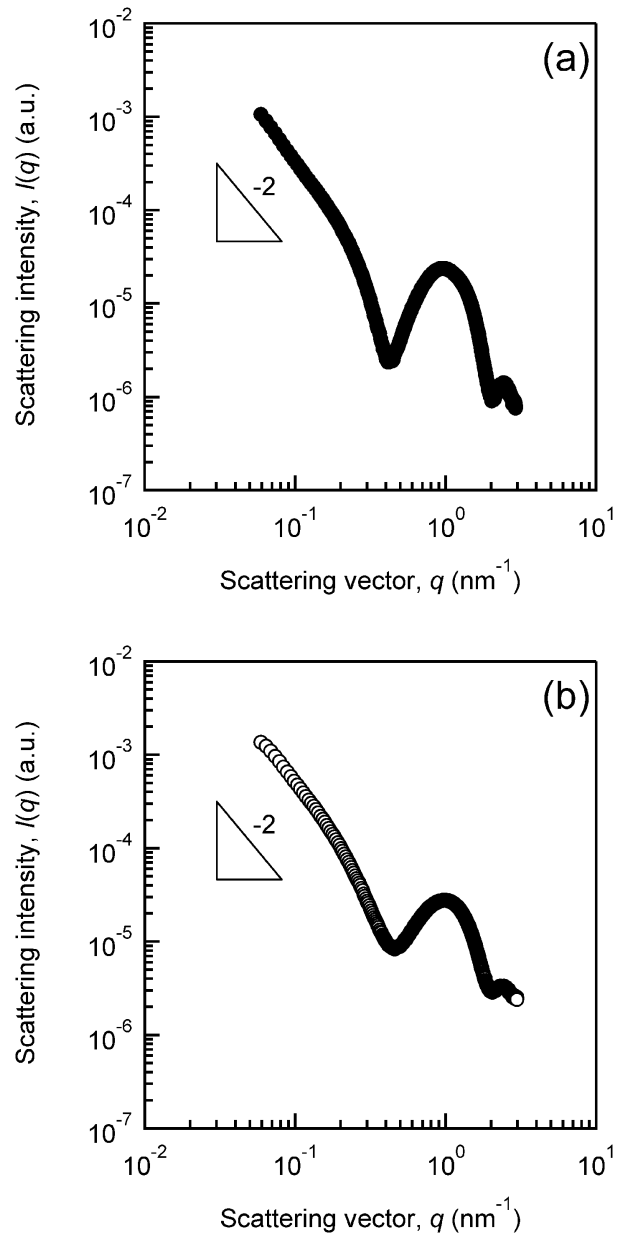

Fig. 3. SAXS Profiles [Scattering Intensity $I(q) v s$. the Scattering Vector $q]$ at $25^{\circ} \mathrm{C}$ for $1.0 \%$ Liposome Suspension (a) and $1.0 \%$ Liposome/0.25\% HM-HPMC Mixed Solution (b)

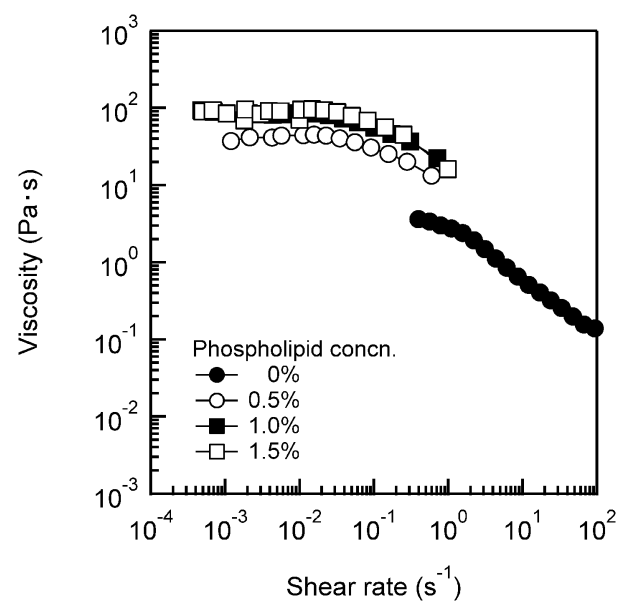

Fig. 4. Steady Flow-viscosity vs. Shear-rate Curves for the Liposome/HM-HPMC Mixed Solution at Various Phospholipid Concentrations at $25^{\circ} \mathrm{C}$

HM-HPMC concentrations were fixed at $0.3 \%$. 


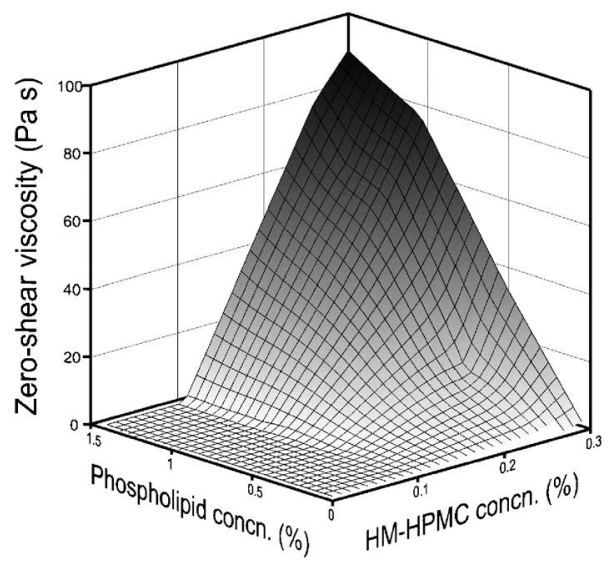

Fig. 5. Zero-shear Viscosity of the Liposome/HM-HPMC Mixed Solution at Various Phospholipid and HM-HPMC Concentrations at $25^{\circ} \mathrm{C}$

$1.5 \%$ のとそれぞれ $0.001013,0.001319 \mathrm{~Pa} \cdot \mathrm{s}$ であ り，リン脂質濃度を変化させてもゼロ剪断粘度はほ とんど変化しない。一方, HM-HPMC 水溶液単独 のゼロ剪断粘度は, HM-HPMC 濃度が $0.1,0.25$, $0.3 \%$ のとそれぞれ $0.002607,0.8365,3.324 \mathrm{~Pa} \cdot \mathrm{s}$ であり，HM-HPMC 濃度に依存してゼロ剪断粘度 は増加したが，この濃度範囲ではゲル化は起こらな い.ところが, リポソーム懸濁液と HM-HPMC 水 溶液を混合すると，リン脂質濃度及び HM-HPMC 濃度に依存してゼロ剪断粘度が急激に上昇した。例 えば， $0.3 \% \mathrm{HM-HPMC}$ 水溶液のゼロ剪断粘度と $1.5 \%$ リ゚ソーム $/ 0.3 \%$ HM-HPMC 混合溶液のそ れを比較すると, リポソーム懸濁液との混合によっ て $3.324 \mathrm{~Pa} \cdot \mathrm{s}$ から $94.89 \mathrm{~Pa} \cdot \mathrm{s}$ まで約 30 倍上昇し, ゾル状態からゲル状態へと変化した（Fig. 2)。こ れらの結果から, リン脂質濃度及び HM-HPMC 濃 度に依存して, 架橋点の数及び架橋点につながつて いる部分鎖の数が増えるために粘度が上昇したと考 えられる，ここで，HM-HPMCの疎水基によるア ンカー効果を裏付けるために, 疎水基が導入されて いない HPMC を用いて検討を行った。

Figure 6 には, リポソーム/HPMC 混合溶液中の $\mathrm{HPMC}$ 濃度を $0.3 \%$ に固定し, リン脂質濃度を変 化させた試料の定常流粘度測定の結果を示す。また,

Table 2 には, リポソーム懸濁液, リポソーム $/ 0.3 \%$ HPMC 混合溶液及びリポソーム $/ 0.3 \%$ HM-HPMC 混合溶液のゼロ剪断粘度を示す。結果より，リポ ソーム $/ 0.3 \%$ HPMC 混合溶液のゼロ剪断粘度は 0.01-0.04 Pa・s であり, リポソーム/ $0.3 \% \mathrm{HM}$ -

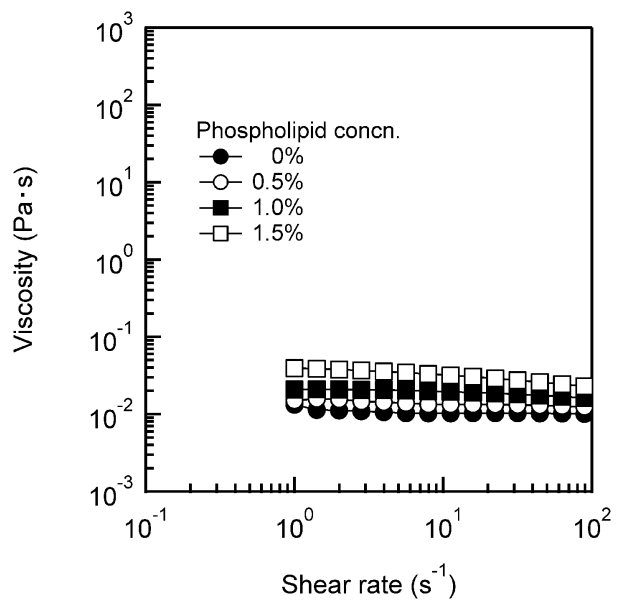

Fig. 6. Steady Flow-viscosity vs. Shear-rate Curves for the Liposome/HPMC Mixed Solution at Various Phospholipid Concentrations at $25^{\circ} \mathrm{C}$

HPMC concentrations were fixed at $0.3 \%$.

HPMC 混合溶液のそれと比較して明らかに低值を 示した。このことから, リポソーム/HM-HPMC 混合系も他のリポソーム/疎水化水溶性高分子混合 系と同様に，疎水基のアンカー効果によってリポ ソームが架橋されていると推察される（Fig. 7).

なお, リポソーム $/ 0.3 \% \mathrm{HPMC}$ 混合溶液のゼロ剪 断粘度がリン脂質濃度の増加に伴い 4 倍程度大きく なったことから，HPMCのメトキシ基やヒドロキ シプロポキシ基がリポソームと相互作用している可 能性が示唆された。

緒言でも触れたように，疎水化水溶性高分子を用 いたリポソーム架橋ゲルに強いずりを加えると, リ ポソームから疎水化水溶性高分子の疎水基が抜け落 ちて粘度が急激に低下することが知られてい る. ${ }^{3-11)}$ そこで, この現象の可逆性を調べるために チクソトロピー性（粘度回復性）を評価した.

Figure 8 には, $1.5 \%$ リ゚ソーム/0.3\% HM-HPMC 混合溶液について, 低剪断速度 $\left(0.5 \mathrm{~s}^{-1}\right)$ の測定か ら高剪断速度 $\left(50 \mathrm{~s}^{-1}\right)$ の測定を経て再び低剪断速 度 $\left(0.5 \mathrm{~s}^{-1}\right)$ の測定を 1 サイクルとし，これを 5 回 繰り返した際の粘度の経時変化を示す．結果より, 各サイクルでほぼ $100 \%$ の粘性回復がみられたこと から，ずりによる架橋構造の崩壊・再生は可逆的で あることがわかった。

次に, リポソーム/HM-HPMC 混合溶液の粘弾 性挙動を調べるために動的粘弾性測定を行った.

Figure 9 には, HM-HPMC の濃度を $0.3 \%$ に固定 し, リン脂質濃度を変化させた混合溶液の $G^{\prime}$ 及び 
Table 2. Zero-shear Viscosity $(\mathrm{Pa} \cdot \mathrm{s})$ of Liposome Suspension, Liposome/HPMC Mixed Solution, and Liposome/HM-HPMC Mixed Solution with Varying Phospholipid Concentrations

\begin{tabular}{lccccc}
\hline & \multicolumn{5}{c}{ Phospholipid concn. (\%) } \\
& 0 & 0.5 & 1.0 & 1.25 & 1.5 \\
\hline Liposome & 0.00089 & 0.001013 & 0.001259 & 0.001186 & 0.001319 \\
Liposome/0.3\% HPMC & 0.01024 & 0.01336 & 0.02068 & 0.02714 & 0.03706 \\
Liposome/0.3\% HM-HPMC & 3.324 & 44.14 & 83.32 & 90.26 & 94.89 \\
\hline
\end{tabular}

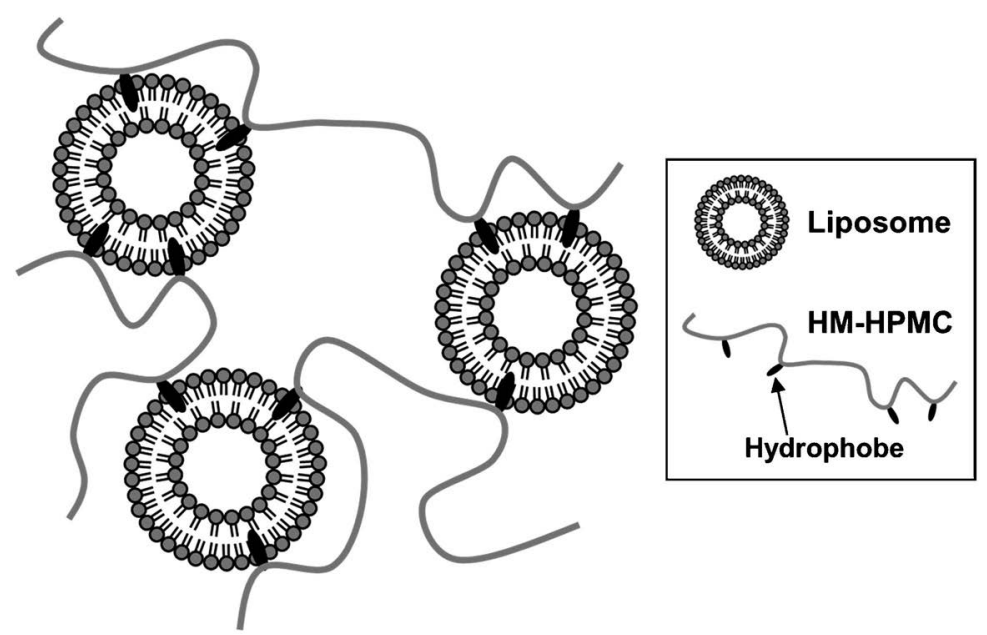

Fig. 7. Schematic Illustration of the Gelation Mechanism of Liposome/HM-HPMC Mixed Solution

$G^{\prime \prime}$ の周波数依存性を示す。ここで， $G^{\prime}$ は弾性すな わち固体としての性質を反映しており， $G^{\prime \prime}$ は粘性 すなわち液体としての性質を反映している。結果よ り, $G^{\prime}$ と $G^{\prime \prime}$ はある周波数で交点を示し，交点より も低周波数側では $G^{\prime \prime}$ が優位で，交点よりも高周波 数側では $G^{\prime}$ が優位であった。このことから，リポ ソーム架橋ゲルは遅い動きに対しては粘性体として ふるまい，速い動きに対しては弾性体としてふるま うことがわかった。また，混合溶液中のリン脂質濃 度が高くなるほど緩和時間 $\left(G^{\prime}\right.$ と $G^{\prime \prime}$ の交点におけ る周波数の逆数值）が長くなり，弾性を示す周波数 領域が広がることもわかった。

\section{結 論}

本研究では, リポソーム/HM-HPMC 混合溶液 のゲル化能やレオロジー特性について検討した。 リ ポソーム懸濁液及び HM-HPMC 水溶液は，それぞ れ単独では粘度が低いが，それらを混合すると粘度 が急激に上昇することがわかった。これは，HMHPMC の疎水基がリポソーム二分子膜中に突き刺 さりリポソーム同士を架橋することで，液全体に 3

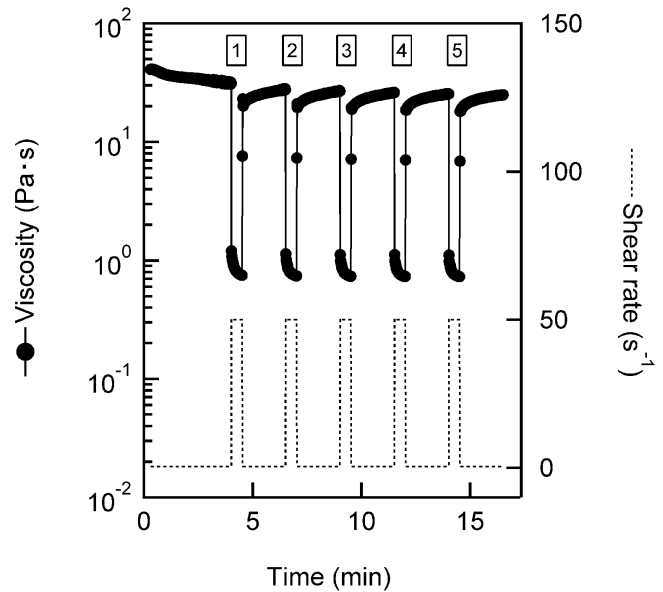

Fig. 8. Cyclic 3-Step Shear Rate $\left(0.5 \mathrm{~s}^{-1} \rightarrow 50 \mathrm{~s}^{-1} \rightarrow 0.5 \mathrm{~s}^{-1}\right)$ Curve of a $1.5 \%$ Liposome/0.3\% HM-HPMC Mixed Solution at $25^{\circ} \mathrm{C}$

次元ネットワーク構造が形成されるためだと考えら れる。.この仮説は，疎水基を持たない HPMC を用 いた場合にはゲル化しないことからも裏付けられ た。また，リポソーム/HM-HPMC 混合溶液の粘 度は外力を加えると急激に減少するが，外力を除く とすぐに元のゲル状態に戻ったことから，この反応 


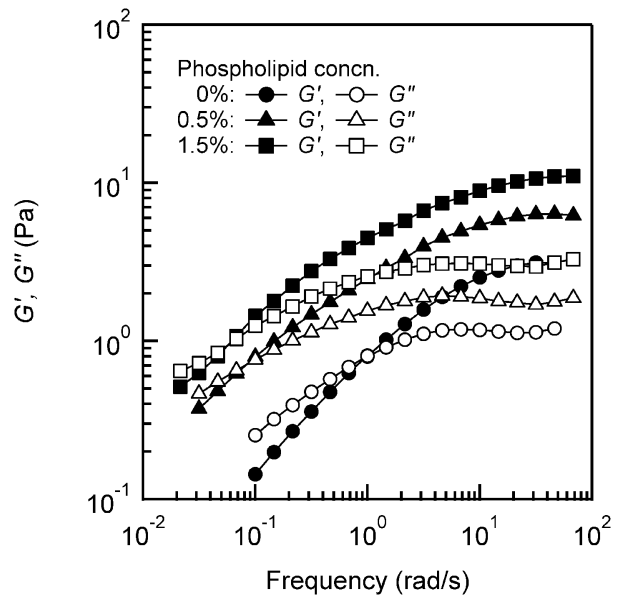

Fig. 9. Variation in $G^{\prime}$ and $G^{\prime \prime}$ as a Function of Frequency at Different Phospholipid Concentrations in the Liposome/ HM-HPMC Mixed Solutions at $25^{\circ} \mathrm{C}$

HM-HPMC concentrations were fixed at $0.3 \%$.

には可逆性があることもわかった．これは，強い外 力が加わるとリポソームから HM-HPMC の疎水基 が抜け落ち, 外力を除くと再びリポソームが架橋さ れるためである.

以上の結果から，HM-HPMC を用いたリポソー ム架橋ゲルは，リポソームとゲルの特性を併せ持っ た興味深い材料であることがわかった。また，その レオロジー特性は従来の水溶性高分子ゲルとは異な ることから，新たな製剤基剤としての利用が期待さ れる，今後は，リポソーム架橋ゲルの安定性に及ぼ す無機塩や pH の影響のほか, リポソームの内封率 に及ぼす HM-HPMC の影響，ゲル製剤からの薬物 の放出性等についても検討したいと考えている.

謝辞サンジェロースを提供して頂いた大同化 成工業株式会社に感謝する. 本稿での研究の一部は, JSPS 科研費 (17K08468), 平成 31 年度日本大学学 術研究助成金総合研究, 平成 31 年度日本大学薬学 部共同研究助成金の支援を受けて行われた。また, SAXS 測定は，大型放射光施設 SPring-8 の BL40B2 ビームラインを利用して行われた（2018A1200）。

利益相反 橋崎 要 (大同化成工業株式会社か らサンジェロースの供与).

\section{REFERENCES}

1) Bangham A. D., Horne R. W., J. Mol. Biol., 8, 660-668 (1964).
2) Hong J. S., Stavis S. M., Lacerda S. H. D., Locascio L. E., Raghavan S. R., Gaitan M., Langmuir, 26, 11581-11588 (2010) .

3) Loyen K., Iliopoulos I., Audebert R., Olsson U., Langmuir, 11, 1053-1056 (1995) .

4) Meier W., Hotz J., Günther-Ausborn S., Langmuir, 12, 5028-5032 (1996).

5) Marques E. F., Regev O., Khan A., Miguel M. D., Lindman B., Macromolecules, 32, 66266637 (1999).

6) Ashbaugh H. S., Boon K., Prud'homme R. K., Colloid Polymer Sci., 280, 783-788 (2002).

7) Antunes F. E., Marques E. F., Gomes R., Thuresson K., Lindman B., Miguel M. G., Langmuir, 20, 4647-4656 (2004) .

8) Lee J. H., Gustin J. P., Chen T., Payne G. F., Raghavan S. R., Langmuir, 21, 26-33 (2005) .

9) Dowling M. B., Kumar R., Keibler M. A., Hess J. R., Bochicchio G. V., Raghavan S. R., Biomaterials, 32, 3351-3357 (2011).

10) Lee J. H., Oh H., Baxa U., Raghavan S. R., Blumenthal R., Biomacromolecules, 13, 33883394 (2012).

11) Oh H., Javvaji V., Yaraghi N. A., Abezgauz L., Danino D., Raghavan S. R., Soft Matter, 9, 11576-11584 (2013).

12) The Japanese Pharmacopoeia Seventeenth Edition, Official monographs, Hypromellose.

13) "Japanese Pharmaceutical Excipients 2018," Yakuji Nippo Limited, Tokyo, 2018, p. 432.

14) Saitoh I., Ikeda K., Takehara M., Takagishi Y., Obara S., Muto H., Yakuzaigaku, 52, 272-279 (1992).

15) Kitamura T., Gang A., Shimizu Y., Shimamoto T., FRAGRANCE JOURNAL, 35(7) , 7277 (2007).

16) Frühwirth T., Fritz G., Freiberger N., Glatter O., J. Appl. Cryst., 37, 703-710 (2004).

17) "Colloid Sciences IV: Experimental Methods for Colloid Sciences,", ed. by the Chemical Society of Japan, Tokyo Kagaku Dojin, Tokyo, 1996, pp. 72-75.

18） Matsuoka H., J. Cryst. Soc Jpn., 41, 213-226 (1999) .

19) Aoki A., Akaboshi H., Ogura T., Aikawa T., Kondo T., Tobori N., Yuasa M., J. Oleo Sci., 64, 233-242 (2015). 